Article

\title{
Evolution of Collaborative Networks Supporting Startup Sustainability: Evidences from Digital Firms
}

\author{
Renato Passaro ${ }^{1}$, Ivana Quinto ${ }^{2, *}$, Pierluigi Rippa ${ }^{2}$ and Antonio Thomas ${ }^{1}$ \\ 1 Department of Engineering, University of Naples Parthenope, 80143 Naples, Italy; \\ renato.passaro@uniparthenope.it (R.P.); antonio.thomas@uniparthenope.it (A.T.) \\ 2 Department of Industrial Engineering, University of Naples Federico II, 80125 Naples, Italy; \\ pierluigi.rippa@unina.it \\ * Correspondence: ivana.quinto@unina.it
}

Received: 13 October 2020; Accepted: 11 November 2020; Published: 13 November 2020

check for updates

\begin{abstract}
The aim of this paper is to investigate whether startup evolution can be conceptualized in a life cycle model intended as an unpredictable sequence of stages, where startups need to find actors with whom to collaborate to acquire knowledge and resources supporting the effectiveness and the sustainability of their mission. The creation and implementation of collaborative networks is observed through the lens of the holistic approach to the entrepreneurial ecosystem, whose purpose is to build "bridges" between different actors through the creation of communities of best practices or entrepreneurial networks. The creation of a specific ecosystem is suggested to ease the new digital entrepreneurship generation toward acquiring an appropriate level of knowledge, skills, financial facilitations, and entrepreneurial culture. Following a multiple case study analysis based on nine successful Italian digital firms, the empirical evidence seems to confirm that firms collaborate with different actors in different stages, as knowledge and resource networks play a critical role in sustaining the evolution and success of new firms.
\end{abstract}

Keywords: startup; innovation; ecosystem; life cycle; case study; Italy

\section{Introduction}

The literature (e.g., [1-5]) increasingly maintains that startups are priority channels for social and economic development, industrial change, and renewal. These newly born firms exhibit the potential to enable and support the transition of local areas, and sometimes of whole economies, toward progress, competitiveness, and borderline knowledge by allowing industrial transformations through innovations and new technologies.

Consistent with one of the most famous definitions [6], startups are temporary organizations because, by exploiting an innovation-oriented market opportunity, they can propose a repeatable and scalable business model and grow quickly in terms of sales, the value of production, and/or the number of employees. On the other hand, their destiny is in the failure of being taken over by other companies, either entirely or as a business idea.

Statistically, during the first stage of operations (typically $3-5$ years) more than $60 \%$ of startups fail around the world [7-9]. Failure is due to the high competition and their operation in chaotic, rapidly evolving, and uncertain contexts while being constrained by limited resources. In fact, despite startups showing more inventive capabilities than established firms, they have to face several different challenges during their life cycles, which can acquire diverse shapes and intensities in each phase [10,11]. The reasons for this are the lack of appropriate financial resources; team and human resource management problems; a lack of proper business and managerial knowledge; technology lag; perceived risks by suppliers of startups (e.g., [12-14]). In other words, startups have to struggle for their survival and existence [15], 
thus, owning a brilliant business idea is not enough. The failure may depend on factors independent of the proposal. Naturally, high failure rates can have negative consequences on the economic system. On the one hand, seed costs constantly increase, discouraging aspiring entrepreneurs from starting a business; on the other hand, they slow down the rate of diffusion of innovation and business ideas in a territorial context.

Researchers agree that a way to sustain and to increase their probability of survival is to build a set of collaborative relationships with different actors in the business ecosystem [16-20] (e.g., venture capitalists and business angels, education system actors, innovation agencies, science parks, external partners, suppliers, etc.) through which they can fill the knowledge and resources gaps and overcome different challenges effectively. A network of collaborative relationships can be found in the context of the holistic approach to the entrepreneurial ecosystem [21], where a set of interconnected actors rooted in the entrepreneurial community formally and informally support new entrepreneurs by providing bottom-up measures to support new venture formations and their success [22,23].

In particular, these different organizations, people, and institutions (actors) have specific functions and they support startups in specific development stages. In this context, digital technologies represent an additional critical resource as they define new ways of collaborating with different actors in order to acquire and collect resources. The main challenge for a new venture is the ability to match with the right actors at the right moment of its growing stage. A startup should be aware of the right time to approach a venture capitalist. Sometimes the startup fails because of the lack of capabilities to enter the market, to negotiate with a business angel, to select the appropriate supplier, to internationalize the business.

This paper aims to determine how new digital firms enter the market and flow through different growth stages. Adopting a life cycle approach, we define a sequence of stages from the ideation up to the consolidation/expansion stage, which can favor the analysis, planning, and management of flourishing startups' sustainability. This interpretative framework allows the startups to identify the startup-friendly ecosystem actors capable of providing the necessary resources and of supporting the realization of the key activities in order to enable the successful transition from one life cycle phase to the next one.

The analysis is based on a literature review to synthesize how scholars evaluate the growth stages of a startup; interviews and meetings with experts in the startup field (e.g., venture capitalists, managers of incubators, academics, etc.) to derive a startup life cycle model; and a multiple case study analysis based on nine successful startups to identify different actors in different stages, as knowledge and resource networks play a critical role in sustaining the evolution and success of new firms.

The paper is organized as follows. Section 2 introduces the theoretical background, which informs the development of our startup life cycle model. The methodology is discussed in Section 3, while the findings are presented in Section 4. Finally, Section 5 discusses the results, while Sections 6 and 7 are addressed to conclusions, implications, and the main limitations of the work.

\section{Entrepreneurial Ecosystems, Collaborative Networks and Startup Life Cycles}

The development of digital technologies in the realm of entrepreneurship represents a recent new challenge for entrepreneurs and policy makers [5,24-28]. By modifying products and business processes and recasting economic patterns and business models, digital technologies change the borders and the ways of dealing with the uncertainty inherent in entrepreneurial activities [24,25,27]. The emergence of digital entrepreneurship derives from the actions of these deep changes, whereas new digital ventures must be able to operate in a dynamic context from the point of view of markets, technology, and competition in order to survive and succeed [26]. In this view, [24] suggested the creation of specific environments where digital entrepreneurs can approach an appropriate knowledge base, digital skills, financial facilitations, and entrepreneurial culture. These are elements that work in a systematic fashion in an entrepreneurial ecosystem that are intended as a set of interconnected entrepreneurial actors (organizations, institutions, and processes), "which formally and 
informally coalesce to connect, mediate and govern the performance within the local entrepreneurial environment" [22]. Ref. [23] referred to the ecosystem as entrepreneurial enablers, organizations composed of experts with specific entrepreneurial competencies whose main task is to assure a holistic approach to entrepreneurship [21] that especially considers bottom-up measures providing active input from the entrepreneurial community. Even though each entrepreneurial ecosystem emerges under an inimitable set of specific conditions and circumstances [23], they share some crucial features (the presence of place-based assets; large, successful knowledge-based established businesses; cross-fertilization processes and spillover effects; relationship mediators, connectors, and new firm formation facilitators; universities and research centers; knowledge-based business services; local and foreign investors), which indicate that the new entrepreneurial ventures require relational rather than transactional assistance during the different life cycle stages they experience [28]. These features support the creation and implementation of collaborative networks among the actors of the entrepreneurial ecosystem, whose purpose is to build "bridges" between different actors through the creation of communities of best practices or entrepreneurial networks $[18,22]$. In this way the entrepreneurial ecosystem contributes to overcoming the knowledge and resource gaps that new ventures suffer from, and, in turn, increases their chances of survival and success at various stages of their life cycle $[17,20,25]$.

Several scholars claim that the kinds, the number, and the sequence of activities that nascent entrepreneurs undertake, in particular, during the pre-startup phases, have a significant influence on the ability of nascent entrepreneurs to successfully create new ventures [13,14,29-32].

Startups have to realize different transformations in their intrinsic features related to diverse salient dimensions (e.g., resources, collaboration, business models, number of employees, etc.), which enable them to face new tasks or problems that growth elicits. According to Phelps, Adams and Bessant (2007) [33], it is possible to observe the startup life cycle as a set of states where startups should be equipped with the proper resources and implement different activities in order to overcome possible crises or issues that can occur at different points and to achieve key milestones that support their development pattern. Therefore, the effective transition between different states of the life cycle depends on the acquisition of new necessary resources, the setup/implementation of different activities, and the achievement of key goals. This is often possible thanks to the collaboration with different actors in the business ecosystem and through the development of a collaborative network. Indeed, by participating in collaborative networks, startups can access, develop, and continuously transform the necessary knowledge resources [34]. Besides exploiting the digital technologies, collaboration among actors is enabled by knowledge-sharing platforms and work execution systems such as crowdsourcing and crowdfunding portals, virtual worlds, digital makerspaces, and dedicated social media [35], which distribute the innovation and generativity processes. Digitalization deeply impacts on both new and established firms, allowing the development of a new business model, new products/services, new forms of collaboration.

In early 2000, the researchers began to analyze the life cycle of startups [36,37].

A life cycle model aimed at identifying the stages that startups meet during their lives (identifying actors in the ecosystem startups with whom to collaborate to acquire required knowledge and resources) is here proposed. For each stage, the model identifies the activities, the organizational resources and entrepreneurial traits, the milestones and the external actors that take part in the collaborative network through which startups can get the required knowledge and resources, develop entrepreneurial features, reach specific outcomes, and overcome possible crises and issues, or continue to develop (Table 1). 
Table 1. A startup development model.

\begin{tabular}{|c|c|c|c|c|}
\hline Stages & Ideation & Intention & Startup & Expansion \\
\hline Definition & $\begin{array}{l}\text { Potential idea } \\
\text { generation }\end{array}$ & $\begin{array}{c}\text { Entrepreneurial } \\
\text { intention readiness, } \\
\text { opportunity validation, } \\
\text { and pre-startup activities }\end{array}$ & New venture creation & $\begin{array}{l}\text { Consolidation, } \\
\text { scalability, and } \\
\text { self-sustainability }\end{array}$ \\
\hline $\begin{array}{l}\text { Required resources } \\
\text { and capabilities } \\
\text { (organizational level) }\end{array}$ & $\begin{array}{c}\text { Technical resources } \\
\text { and entrepreneurial } \\
\text { culture }\end{array}$ & $\begin{array}{l}\text { Financial, technical, and } \\
\text { managerial resources }\end{array}$ & $\begin{array}{l}\text { Financial, technical, } \\
\text { physical, and } \\
\text { managerial resources }\end{array}$ & $\begin{array}{c}\text { Financial, } \\
\text { technological, physical, } \\
\text { and managerial } \\
\text { resources }\end{array}$ \\
\hline $\begin{array}{c}\text { Key factors } \\
\text { (individual } \\
\text { startupper level) }\end{array}$ & $\begin{array}{l}\text { Creativity, intuition, } \\
\text { prior experience }\end{array}$ & $\begin{array}{l}\text { Entrepreneurial and } \\
\text { risk-taking orientation, } \\
\text { self-confidence, } \\
\text { motivation }\end{array}$ & $\begin{array}{l}\text { Entrepreneurial and } \\
\text { risk-taking orientation, } \\
\text { self-confidence, } \\
\text { leadership }\end{array}$ & $\begin{array}{l}\text { Leadership, } \\
\text { coordination ability, } \\
\text { strategic orientation }\end{array}$ \\
\hline Key Activities & $\begin{array}{c}\text { Discovering idea, } \\
\text { market opportunity } \\
\text { intuition, resource } \\
\text { needs and availability }\end{array}$ & $\begin{array}{l}\text { Market opportunity } \\
\text { validation, } \\
\text { engagement/commitment, } \\
\text { team building, resource } \\
\text { searching/validation }\end{array}$ & $\begin{array}{l}\text { Business planning, } \\
\text { product and } \\
\text { commercial } \\
\text { development, } \\
\text { searching for } \\
\text { additional funding } \\
\text { resources }\end{array}$ & $\begin{array}{l}\text { Massive customer } \\
\text { acquisition, back-end } \\
\text { scalability } \\
\text { improvements, new } \\
\text { personnel and first } \\
\text { executive hiring, } \\
\text { internationalization }\end{array}$ \\
\hline Milestones & Idea viability & Prototype & Industrialization & Scale-up \\
\hline $\begin{array}{l}\text { Ecosystem actors } \\
\text { (mainly) }\end{array}$ & $\begin{array}{c}\text { Higher education } \\
\text { systems, governor and } \\
\text { local agencies } \\
\text { (entrepreneurial } \\
\text { culture developers) }\end{array}$ & $\begin{array}{c}\text { Higher education } \\
\text { systems, startup } \\
\text { initiatives, family, } \\
\text { friends, business angels, } \\
\text { fab labs, business centers, } \\
\text { Technology Transfer } \\
\text { Offices (TTOs), } \\
\text { incubators }\end{array}$ & $\begin{array}{c}\text { Incubators, } \\
\text { accelerators, } \\
\text { coworking spaces, } \\
\text { crowdfunding } \\
\text { platforms, venture } \\
\text { capitalists, partners } \\
\text { (suppliers, customers, } \\
\text { SMEs, large firms, } \\
\text { startups) }\end{array}$ & $\begin{array}{l}\text { Accelerators, venture } \\
\text { capitalists, partners } \\
\text { (suppliers, customers, } \\
\text { SMEs, large firms, } \\
\text { startups) }\end{array}$ \\
\hline
\end{tabular}

The model was derived by adopting a four-stage life cycle approach discussed in the following:

1. Ideation: the potential startupper (or the team of founders) is focused on the discovery and generation of a possible idea. In particular, he or she tries to understand whether the potential idea represents an innovation that can solve a meaningful problem or satisfy a (latent) consumer need [38]. In other words, he or she aims at grasping whether a market opportunity exists [39]. The potential startupper also begins to define the resources needed and their availability without even considering the possibility of launching a new business. At this stage, crucial startupper traits tend to be creativity, intuition, and prior experience, which support the generation of a potential business idea [39,40]. Moreover, the startupper needs technical resources aimed at analyzing and adequately identifying the idea viability. In this view, the startupper can be endowed with adequate technical resources and an entrepreneurial culture set, and develop the proper personal capabilities. Key actors in this stage are the higher education systems, startup competitions, and local governmental agencies as principal providers of knowledge and supports $[19,41]$. This initial stage is characterized by a great deal of uncertainty [42].

2. Intention: in this second stage the potential startupper is focused on the possibility of converting the idea into a business. It is crucial that the validation (verification) of the market opportunity can be defined as a "moment of truth," where potential customers should show interest in the nascent idea $[31,39]$. At the same time, the startupper begins to define the necessary financial resources and look for initial funds and investors (i.e., family, friends, business angels, business competition) [39]. Moreover, to get technical and managerial resources, the potential startupper must collaborate with some entrepreneurial ecosystem actors (incubators, Technology Transfer Offices, business centers, universities, etc.) $[19,41]$. These resources are crucial to make the intention more stable and viable, as well as to develop a prototype. Therefore, in this phase, the startupper should develop formal and informal relationships with different actors in the startup-friendly ecosystem to get the needed resources, relational capital, and support [43]. Key startupper traits of this stage are 
motivation, risk evaluation and propensity, and self-confidence. This phase can be considered concluded when a prototype (or standard/protocol/beta version, etc.) has been developed.

3. Startup: the startupper launches the new business [44]. Aspiring entrepreneurs are, in this stage, able to measure, quantify the success probability of the business idea, and identify the necessary tangible and intangible resources. Now the potential startupper can also be considered a nascent entrepreneur who seriously commits his or her own time and efforts to founding a viable new independent venture [45]. The startup phase consists of technological and commercial development and formal business planning, as well as the searching for additional and more considerable funding resources $[46,47]$. To this purpose, startups can seek help from traditional sources (financial institutions, capital ventures) [48,49], as well as from crowdfunding platforms [50,51]. Moreover, in this stage, an important role must be assigned to incubators, accelerators, and coworking spaces able to get further managerial, technical, and physical resources. Startups should be able to make agreements or enter into contracts with reliable customers and suppliers as well as develop relationships with other external partners. The key startupper features are entrepreneurial and risk-taking orientation, self-confidence, and leadership. Finally, in this stage the new product/service is launched on the market and startups should be able to issue the first invoice.

4. Expansion: according to Blank and Dorf (2012) [6], the startup has to become self-sustainable. The startupper should develop new skills such as handling a higher turnover, motivating and coordinating an increasing number of employees, relating with new customers and suppliers, looking for international markets and partners, and also developing the ability to delegate growing tasks and activities. Also, startuppers should exhibit multifaceted and complex competencies and abilities in terms of leadership, strategic orientation and coordination [52,53], and funding opportunities search $[46,47]$. Key activities in this stage are massive customer acquisition, back-end scalability improvements, new personnel and first executive hiring, internationalization, supplier selection. To comprehend if and how the proposed four-stage model is able to express and interpret the process of forming a startup through the stages of its life cycle, the model was verified and validated through a multiple case approach. In particular, this model aims to explore: (i) how the startups go through each of the different stages and, thus, face the different challenges; (ii) what competences and resources are necessary in each stage to successfully achieve the different goals and milestones; (iii) which actors in the entrepreneurial ecosystem need to be involved in each stage and why.

\section{Research Method and Data Collection}

Understanding the life cycle of a startup requires insight into how founders conceptualize responses to each stage of the proposed model. It is also essential to consider how the new firm interacts with external actors, which competences and resources are critical to reaching a new stage, and which key activities are essential to entering into the final stage. Therefore, researchers must attempt to identify the deep-seated values and assumptions that underpin managerial sense-making activities.

A triangulation approach of more data sources was adopted in this research to propose and verify the startup's life cycle model. To validate the startup life cycle model defined according to the related literature review on this topic, a set of eight interviews with a panel of experts in the startup field (three venture capitalists, a director of a startup competition, an incubator manager, three academics) was performed. In particular, during the interviews, we asked them to verify the coherence of the model based on their experience. Each interview lasted $60 \mathrm{~min}$, during which, first of all, the model was thoroughly presented. Then the interviewees, based on their experience, expressed their opinions about the coherence and validity of the identified stages and the related resources, activities, and milestones. In conclusion, the startup life cycle model was defined according to both the results deriving from the literature review and some expert interviews. 
Additionally, in order to verify the coherence of the model we developed according to the literature review and modified based on the experts' suggestions and comments, a multiple case approach was adopted (Figure 1).

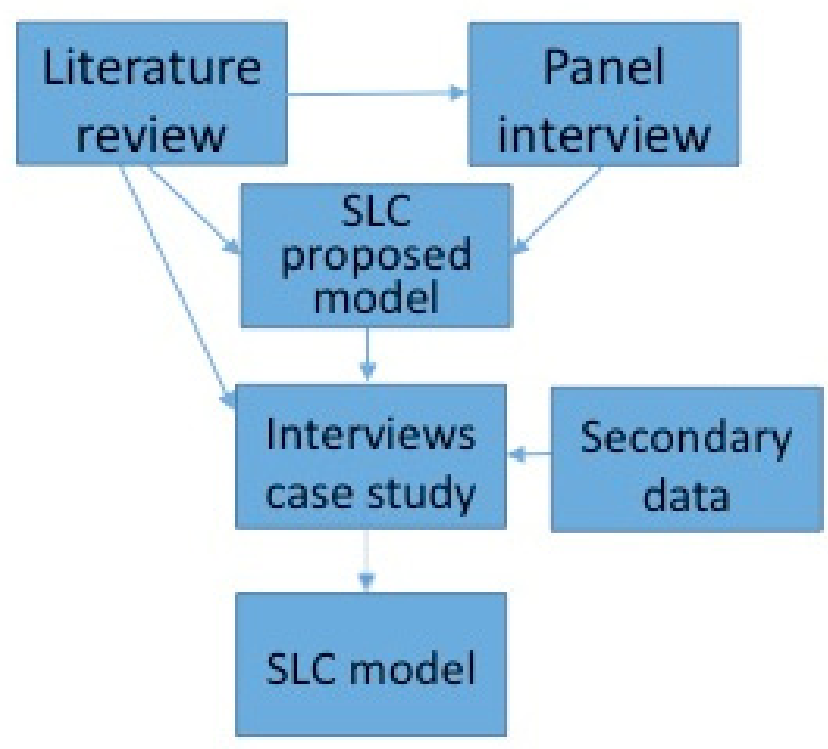

Figure 1. Research methodology adopted.

As is well-known, this methodology allows analysis of issues from different standpoints. It is considered an appropriate method for gathering the necessary data and information to facilitate an in-depth understanding of how startups evolve all along their life cycle [54]. In this paper nine case studies were realized, which was consistent with the suggestions (4-10 cases) by Eisenhardt (1989) [55] and (6-10 cases) by Yin (2003) [56].

Semi-structured interviews provided the main source of data and focused on individual and group decisions related to specific episodes that characterized each stage. Interviews were guided by a case study protocol [55-57] based on inputs from the innovation and entrepreneurship literature. Moreover, for each case study

- the development path followed by each startup was developed;

- a cross-case analysis was carried out to identify the similarities and differences among the case studies;

- the results of the empirical evidence were continuously compared with the information from the theoretical setting to refine, enrich, and modify the theoretical framework developed.

By investigating responses to each stage (ideation, intention, startup, expansion) interviewees were encouraged to reflect on how they and their organizations adapted to situations of uncertainty and ambiguity. This required an in-depth reflection on key underlying reasons for particular responses [58]. According to this plan, we interviewed a total of 10 founders and six CEOs from the nine startups at least twice to obtain complete responses to all our questions. As key respondents, they appeared to be the proper individuals as they had followed the startup from the idea generation to the moment of the interview (Table 2). 
Table 2. Details about interviews.

\begin{tabular}{cccc}
\hline Startup & Interviewees & $\begin{array}{c}\text { Length of First Round } \\
\text { of Interviews }\end{array}$ & $\begin{array}{c}\text { Length of Second } \\
\text { Round of Interviews }\end{array}$ \\
\hline $\mathrm{A}$ & Founder and CEO & $2.5 \mathrm{~h}$ & $1.5 \mathrm{~h}$ \\
$\mathrm{~B}$ & Founder & $2.5 \mathrm{~h}$ & $1.5 \mathrm{~h}$ \\
$\mathrm{C}$ & Founder and CEO & $2 \mathrm{~h}$ & $1.5 \mathrm{~h}$ \\
$\mathrm{D}$ & Founder and CEO & $3 \mathrm{~h}$ & $2 \mathrm{~h}$ \\
$\mathrm{E}$ & Two Founders & $3 \mathrm{~h}$ & $2 \mathrm{~h}$ \\
$\mathrm{~F}$ & Founder and CEO & $2.5 \mathrm{~h}$ & $1 \mathrm{~h}$ \\
$\mathrm{G}$ & Founder and CEO & $3 \mathrm{~h}$ & $1.5 \mathrm{~h}$ \\
$\mathrm{H}$ & Founder and CEO & $2.5 \mathrm{~h}$ & $1 \mathrm{~h}$ \\
$\mathrm{I}$ & Founder & $2 \mathrm{~h}$ & $1 \mathrm{~h}$ \\
\hline
\end{tabular}

Finally, we validated all the information collected from the key respondents with secondary sources of information, such as reports of companies, websites, startup databases, or the same reference sources used for identifying the companies or experts in the field familiar with the startups [55,59].

Startups to be included in the analysis were selected, starting from a pool of startups proposed by the experts enrolled in the model definition. The main criteria adopted to select the startup firms to be included in the research were: (i) Each firm must be active for at least three years; (ii) The startups have to be listed in the Register of Innovative Startups proposed by the Italian Minister of Economic Development (MISE) [60]; (iii) They must have been operative on the market in the year 2018.

The group of researchers who participated in the data collection audio-recorded all the interviews for subsequent transcription. Respondents reviewed the resulting write-ups as a precaution against misunderstandings and errors of transcription [57]. Literature results, analysis of the inputs from the in-depth interviews, focus group discussions, and secondary sources led us to identify, per each stage of the proposed model, the required resources and capabilities, key startupper factors, critical activities, milestones, and ecosystem actors. Interviews were conducted with the support of an interview guide largely derived from the model and the literature analysis.

Validation of the written-up inputs optimized their internal validity and reliability [57,61], thereby substantiating the conclusions drawn [57].

The following section is divided by subheadings. It provides a concise and precise description of the experimental results, their interpretation, as well as the experimental conclusions that can be drawn.

\section{Data Analysis and Results}

This paper used an exploratory multiple case study analysis of nine startups operating in different industries (e.g., civil engineering, Information and communication technologies (ICT), consultancy, etc.) and varying in size, market, dimension, and age. For each firm, we provided a brief profile description, geographical location, the sector of activity (Table 3 ). 
Table 3. Descriptive data about interviewed startup.

\begin{tabular}{|c|c|c|c|c|c|c|}
\hline $\mathbf{N}$ & Case (Brief Profile) & Sector & Product/Service & Region & Founder & Market \\
\hline 1 & $\begin{array}{l}\text { Startup A was founded in } 2009 \text { by a family member of a civil engineering company. The firm started from } \\
\text { the idea of its founder to solve a production problem of the family firm. As the founder understood the } \\
\text { idea had a potential market, he created a new venture to technically improve the new product. Two other } \\
\text { members were involved in the journey. All the members had strong technical competences. }\end{array}$ & Civil engineering & $\begin{array}{l}\text { Plant for producing } \\
\text { construction } \\
\text { premixes }\end{array}$ & Calabria & $\begin{array}{l}\text { Three partners with } \\
\text { technical skills }\end{array}$ & $\begin{array}{l}\text { Domestic and } \\
\text { International }\end{array}$ \\
\hline 2 & $\begin{array}{l}\text { Startup B started formally in 2012, when a young employee working with his family in the railway sector } \\
\text { imagined a new and innovative product. The startupper was inspired by the total lack of green products } \\
\text { in that sector. The startup is now operative, and it operates at an international level, especially in the USA. }\end{array}$ & Railway & Sustainable sleepers & Sicily & $\begin{array}{l}\text { One member with } \\
\text { technical skills }\end{array}$ & $\begin{array}{l}\text { Domestic and } \\
\text { International }\end{array}$ \\
\hline 3 & $\begin{array}{c}\text { Startup C was founded in } 2012 \text { by an engineering student (former startupper) and an ICT professional } \\
\text { partner. Today it is one of the leaders of the Italian crowdfunding market, having raised over EUR } \\
3,000,000 \text { in few years. The startup has branches in Naples and Milan and has been cited in several } \\
\text { national and international press articles. }\end{array}$ & $\begin{array}{l}\text { Innovative finance } \\
\text { service }\end{array}$ & $\begin{array}{l}\text { Crowdfunding } \\
\text { platform }\end{array}$ & Campania & $\begin{array}{l}\text { Two partners with } \\
\text { ICT skills }\end{array}$ & $\begin{array}{l}\text { Domestic and } \\
\text { International }\end{array}$ \\
\hline 4 & $\begin{array}{l}\text { Startup D is a leader firm in Italy in the influence engine optimization platform market. The company } \\
\text { was founded in } 2013 \text { by a team of young professionals. The startup has branches in Rome, Milan, London, } \\
\text { and a planned opening in New York. From } 2014 \text { to the present the company has grown very fast, gaining } \\
\text { a great visibility at the international level. The platform boasts a database of over 90,000 influencers and } \\
\text { has received awards in the EU and USA. }\end{array}$ & $\begin{array}{l}\text { Social Media } \\
\text { Mining }\end{array}$ & $\begin{array}{l}\text { Influence engine } \\
\text { optimization } \\
\text { platform }\end{array}$ & Campania & $\begin{array}{l}\text { Team with } \\
\text { technical skills }\end{array}$ & $\begin{array}{l}\text { Domestic and } \\
\text { International }\end{array}$ \\
\hline 5 & $\begin{array}{l}\text { Startup E was founded in Pescara in } 2014 \text { by four engineers, formerly managers for large firms in the } \\
\text { energy industry. Around 2007/2008 they left the companies for professional/entrepreneurial activities } \\
\text { (photovoltaic energy design and realization for small firms). The startup has new branches also in Rome } \\
\text { and Milan. From } 2014 \text { to the present the company has grown very quickly, both in terms of turnover and } \\
\text { number of employees. }\end{array}$ & Energy & $\begin{array}{l}\text { Energy } \\
\text { management } \\
\text { services }\end{array}$ & Abruzzo & $\begin{array}{l}\text { Four founders with } \\
\text { firm-specific skills } \\
\text { developed thanks to } \\
\text { prior experiences }\end{array}$ & $\begin{array}{c}\text { Domestic } \\
\text { market }\end{array}$ \\
\hline 6 & $\begin{array}{l}\text { Startup F was founded in Rome in September } 2014 \text { by four individuals with different competences, that is, } \\
\text { a freelance computer engineer, a designer, and an expert on fashion. The startup was presented as one of } \\
\text { the best cases in the world for the use of a specific wireless technology. In the last years, the startup has } \\
\text { grown strongly, and is also launching a process of productive diversification. }\end{array}$ & ICT & Tracking device & Lazio & $\begin{array}{l}\text { Four founders with } \\
\text { different skills } \\
\text { (design, fashion, } \\
\text { engineering) }\end{array}$ & $\begin{array}{l}\text { European and } \\
\text { Domestic } \\
\text { market }\end{array}$ \\
\hline 7 & $\begin{array}{l}\text { Startup G was founded in } 2015 \text { by four young and brilliant entrepreneurs, all under the age of } 30 \text { and with } \\
\text { very different professional experiences. The startup is Italy's leading developer of dynamic pricing } \\
\text { solutions for ticketing and beyond, with branches in Milan and Rome. }\end{array}$ & Entertainment & $\begin{array}{l}\text { Developer of } \\
\text { dynamic pricing } \\
\text { solutions for } \\
\text { ticketing }\end{array}$ & Lombardia & $\begin{array}{l}\text { Four founders with } \\
\text { different skills } \\
\text { (engineering, } \\
\text { marketing, fashion) }\end{array}$ & $\begin{array}{l}\text { European and } \\
\text { Domestic } \\
\text { market }\end{array}$ \\
\hline 8 & $\begin{array}{l}\text { Startup H was funded in } 2015 \text { by two brilliant engineers with different prior experiences. It offers its } \\
\text { customers a participatory and Customer Relationship Management (CRM) tool that allows the integration } \\
\text { and sharing of all information (e.g., e-mails, personal notes and files, calendar appointments and } \\
\text { assignments) generated when starting a business collaboration. Nowadays, the Startup H operates in } \\
\text { different European countries. }\end{array}$ & ICT & $\begin{array}{l}\text { Cloud platform for } \\
\text { CRM }\end{array}$ & Trentino & $\begin{array}{l}\text { Two founders with } \\
\text { different skills } \\
\text { (design, HR, } \\
\text { software) }\end{array}$ & $\begin{array}{c}\text { European } \\
\text { market }\end{array}$ \\
\hline 9 & $\begin{array}{l}\text { Startup I was founded in } 2014 \text { by an engineer and an economist. Company I can offer an integrated } \\
\text { software platform that also works remotely to automatically record the purchase invoices of a company } \\
\text { without changing the accounting program. This system helps organizations save time and space (paper } \\
\text { documents) and minimize the possibility of error. The startup has important partners (e.g., one of the big } \\
\text { consultant organizations in Italy) and it was able to double its turnover in a very few times. }\end{array}$ & ICT & $\begin{array}{l}\text { Software for } \\
\text { accounting and } \\
\text { effective invoice } \\
\text { management }\end{array}$ & Sardinia & $\begin{array}{l}\text { Two founders with } \\
\text { different skills } \\
\text { (engineer, } \\
\text { management) }\end{array}$ & $\begin{array}{c}\text { Domestic } \\
\text { market }\end{array}$ \\
\hline
\end{tabular}


The evolution of the turnover and the number of employees over time are shown in Table 4. Initially, a total of 14 startup firms were analyzed and selected. Due to noncompliance with the requirements, five startups were not considered and, thus, only nine startups were interviewed as representative of the phenomenon under observation.

Table 4. Dimensional data of interviewed startups.

\begin{tabular}{|c|c|c|c|c|c|c|c|c|c|}
\hline & \multicolumn{9}{|c|}{ Turnover } \\
\hline Startups & 2010 & 2011 & 2012 & 2013 & 2014 & 2015 & 2016 & 2017 & 2018 \\
\hline \multirow{2}{*}{ A } & EUR & EUR & EUR & EUR & EUR & EUR & EUR & EUR & EUR \\
\hline & 359.102 & 1178.970 & 1330.840 & 2299.398 & 2522.340 & 1476.827 & 1609.819 & 2347.151 & 1589.552 \\
\hline \multirow{2}{*}{ B } & \multirow[b]{2}{*}{ - } & \multirow[b]{2}{*}{ - } & & \multirow{2}{*}{ EUR 5} & \multirow{2}{*}{ EUR 8} & EUR & EUR & EUR & \\
\hline & & & & & & 200.520 & 347.934 & 1091.524 & \\
\hline \multirow{2}{*}{ C } & \multirow{2}{*}{ - } & \multirow[b]{2}{*}{ - } & EUR & EUR & EUR & EUR & EUR & EUR & EUR \\
\hline & & & 54.762 & 228.206 & 85.919 & 263.044 & 240.055 & 239.476 & 241.768 \\
\hline \multirow{2}{*}{$\mathrm{D}$} & \multirow{2}{*}{ - } & \multirow[b]{2}{*}{ - } & \multirow[b]{2}{*}{ - } & EUR & EUR & EUR & EUR & EUR & EUR \\
\hline & & & & 59.296 & 196.726 & 1193.774 & 3126.998 & 4284.756 & 5536.251 \\
\hline \multirow{2}{*}{$\mathrm{E}$} & \multirow[b]{2}{*}{ - } & \multirow[b]{2}{*}{-} & \multirow[b]{2}{*}{-} & \multirow[b]{2}{*}{ - } & EUR & EUR & EUR & EUR & EUR \\
\hline & & & & & 701.464 & 386.088 & 1030.585 & 1737.975 & 1419.968 \\
\hline \multirow{2}{*}{$\mathrm{F}$} & \multirow{2}{*}{ - } & \multirow[b]{2}{*}{ - } & \multirow[b]{2}{*}{ - } & \multirow[b]{2}{*}{ - } & EUR & EUR & EUR & EUR & EUR \\
\hline & & & & & 5.159 & 280.037 & 763.728 & 993.787 & 1166.559 \\
\hline \multirow{2}{*}{ G } & \multirow{2}{*}{ - } & \multirow[b]{2}{*}{ - } & \multirow[b]{2}{*}{-} & \multirow[b]{2}{*}{ - } & 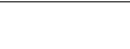 & FUR & EUR & EUR & EUR \\
\hline & & & & & - & EUKU & 14.557 & 148.657 & 338.472 \\
\hline $\mathrm{H}$ & 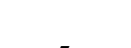 & 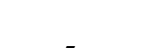 & 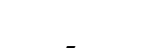 & 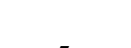 & 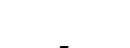 & EUR & EUR & EUR & EUR \\
\hline $\mathrm{H}$ & - & - & - & - & - & 59.497 & 177.845 & 264.884 & 556.413 \\
\hline I & - & _- & _ & & FUR 0 & FUR 3 & EUR & EUR & EUR \\
\hline 1 & - & - & - & - & EUR 0 & EUR 3 & 108.934 & 243.542 & 495.098 \\
\hline & & & & & Employee & & & & \\
\hline A & nd & 9 & 14 & 10 & 20 & 22 & 22 & 20 & 19 \\
\hline B & - & - & - & - & - & 5 & 11 & 8 & nd \\
\hline $\mathrm{C}$ & - & - & 5 & 5 & 1 & 1 & 2 & 5 & 3 \\
\hline $\mathrm{D}$ & - & - & - & - & 3 & 10 & 26 & 47 & 50 \\
\hline $\mathrm{E}$ & - & - & - & - & 3 & 3 & 5 & 6 & 6 \\
\hline F & - & - & - & - & - & 3 & 7 & 9 & 13 \\
\hline $\mathrm{G}$ & - & - & - & - & - & nd & 6 & 7 & 6 \\
\hline $\mathrm{H}$ & - & - & - & - & - & 1 & 4 & 3 & 5 \\
\hline I & - & - & - & - & nd & 6 & 7 & 8 & 9 \\
\hline
\end{tabular}

We believe that this sample of companies adequately fit with the theoretical setting and, therefore, it was a suitable response to the research question proposed in the State-of-the-art section, as companies were

- Heterogeneous for dimension, geographic location, number of employees, and sector of activity, and in illustrating differences in how startups follow their development paths and whether and how contextual factors can impact on organizational performances;

- Homogeneous for the stages that startups overcome along with their life cycles, which helped us to highlight similarities and differences in terms of the resources and capabilities exploited and actors with whom they collaborated. 
According to [55,62], multiple case study analysis allows answering "how" and "why" questions and is particularly appropriate for cross-case comparisons.

Our multiple case study analysis showed that the evolution paths followed by the startups appeared to be consistent with the life cycle model defined based on the literature review. Specifically, the model is made up of four phases, each of which is characterized by different: (i) needs in terms of resources and capabilities at organizational and startupper individual levels (e.g., founder); (ii) activities to be performed; (iii) relationships to develop with diverse actors of startup-friendly ecosystems.

According to the results derived from the multiple case study analysis, each phase was thoroughly analyzed and discussed. In the following sub-sections, the main traits of these companies related to the life cycle features depicted are provided.

\subsection{Ideation Stage}

All the startups confirmed that this phase is very crucial to understand if the potential business idea represents an innovation able to solve a meaningful problem or satisfy a latent customer's need (e.g., $[38,39])$.

The founder of the Startup A claimed that "University background and prior professional experiences allowed to evaluate the feasibility of the business idea."

The founder of Startup B also confirmed the importance of intuition in this stage. He claimed that "I was able to have a good intuition above all thanks to prior experiences in my family business and to my university background."

The founder of the Startup D also agreed and, indeed, he affirmed that "The idea was born by observing the web influencers' behaviors and the effects on the customers' purchases ... during a startup competition organized by a public administration in our city."

Creativity and intuition were particularly important also for Startup F during the initial phase of the entrepreneurial processes. The founder claimed that "My colleagues and I met each other during the participation in a startup competition.... . During the initiative, we identified a problem to be solved and started to define the business idea."

Intuition played a critical role also in the ideation of the business idea of Startup G. In particular, the startup's CEO told us "... we had an intuition, ... Thanks to technical skills about ICT and Artificial Intelligence tools, matured mainly during our university study."

According to this, the presence of technical skills appeared to be another critical enabler of the launch of a startup, as also confirmed by the founders of the Startup C, specifically, "During the ideation stage, the possession of technical competences (ICT and WEB-based) let me and my co-founders work adequately on the proof of concept."

In the cases of the Startups E, $\mathrm{H}$ and I high industry-specific knowledge played a relevant role in the recognition of a market opportunity. Indeed, as claimed by one of the founders of Startup E, "Previous work experiences in this sector let us develop a strong and advanced high industry-specific knowledge which proved to be fundamental for the identification of the new market opportunity."

The founder of Startup H confirmed the importance of industry-specific knowledge developed during both past work experiences and his university study. In particular, he claimed that “The possibility to work for some years in the ICT industry let me to know the customers' needs deeply and to develop additional specific-industry knowledge and competences which were fundamental for the launch (and success) of our startup."

Similarly, the founder of Startup I argued that "In the right time I became aware of the potential know-how and competences developed during my previous work experiences ... . "

In synthesis, the cases confirmed the literature that showed how creativity, intuition, and past experiences are key startupper traits [54], while, at an organizational level, technical resources were considered critical for the generation of a potential business idea and the evaluation of its viability. Founders aimed at identifying the actors and stakeholders (e.g., the higher education systems, business 
angels, startup competition, etc.) able to equip them with such lacking tangible and intangible assets (e.g., $[16,17,20])$.

\subsection{Intention Stage}

The intention stage is the test of the possibility to transform the idea into a business. According to this, startuppers must develop formal and informal relationships with different actors of the startup-friendly environment to verify the validity of the business idea and to get technical, managerial, and financial resources (e.g., $[16,20])$.

As argued by the founder of Startup A, "The participation in different startups' contests were crucial for our team as it lets to develop several relationships with different actors, as well as strengthen our motivation and self-confidence."

The founder of Startup C claimed that "In this second stage, it was crucial to get in touch with some investors ... The development of such a relationship had a positive impact also on our motivation and self-confidence."

Similarly, the transition to the intention stage of Startup D happened when the founders, participating in a business plan competition, won a web services prize. As stated by one of the founders, "By participating to an international business plan competition, ... the award ... help us in the development of an early prototype of the platform."

The founder of Startup F argued that "The participation in a pre-acceleration program allowed us to access to managerial, physical and technological resources. This give us new energy to go on, increasing further our motivation and self-confidence too."

As confirmed by the founder of Startup I, "In this stage, ... through a crowdfunding campaign, we were able to collect more than 200,000 euros to invest in the improvement of our software."

This was not the case for Startups B and H, as the development of different relationships represented the most essential "triggering" event for the transition along the entrepreneurial process. Indeed, as argued by the founder of Startup B, "Me and my colleagues contacted several universities and research centers to find the right technical competences that let us develop at least a prototype of our product. Finally, thanks to the collaboration with a leading Italian university, we were able to support the development of our idea." Similarly, the founders of Startup H highlighted that "The meeting with an expert algorithm developer with many years of experience in the sector was crucial for the success of own startup."

Finally, the founder of Startup E claimed that motivation, self-confidence, and a risk-taking attitude were crucial for not giving up this entrepreneurial initiative. In particular, he argued that "... due to our self-confidence and motivation we tried to re-define the business idea and to identify a more effective business model. ... a lean energy management model was proposed and tested."

In this stage, financial resources were mainly exploited to fund the development of a prototype and the evaluation of the market opportunity. Finally, key startupper traits of this stage were motivation, risk evaluation and propensity, and self-confidence. The critical role played by the financial resources was recognized not only in the literature [51] but also by the sampled startups.

\subsection{Startup Stage}

The startup stage represents the launch of a new venture after the feasibility of the business idea has been careful evaluated [44]. The startupper is now a nascent entrepreneur who seriously commits his or her own time and efforts to founding a viable new independent firm [45].

The relevance of a considerable loan to launch a startup was confirmed by the founder of Startup A, who at claimed "... The investment allowed opening a plant to begin the product industrialization, as well as the acquisition of the needed managerial competences."

Similarly, the founder of Startup B argued that " ... the incubation allowed us to access additional managerial, physical and technical competences. The incubator facilitated also the development of key partnerships with different actors..." 
As argued by the founder of Startup C, "The occurring of early stage financing operations allowed us to launch our platform, found a new venture and, thus, enter into the startup stage." Also, for the founder of Startup D, "The launch of the startup was possible thanks to a seed financing offered by a leading Italian incubator which allowed us to get contacts with new partners, to improve the platform (beta version), to open our own headquarter and hire young, competent people." Similarly, the founder of Startup E stated that "The transition into startup stage happened when we got a seed financing by two public institutions and a bank financing."

The founders of Startups F and G confirmed the importance of getting considerable financial resources for the starting-up; indeed, as affirmed by the founder of Startup F, "The new venture was funded thanks to a further pre-seed financing by a venture capitalist. Venture capitalists were critical players as they provided us also managerial, legal, marketing and business development management competences." The same was confirmed by the founder of Startup G, who claimed that "To obtaining a consistent loan by a leading Italian venture capital lets us to work strongly on the development and improvement of our platform."

The founder of Startup I declared that the financial resources were very critical for the launch of the new venture, but technical resources were, however, considered important complementary assets. Specifically, he stated that "For the launch of our startup two events were fundamental, namely to getting a financing by an Italian venture capital and the development of a formal relationship with an university. These two events allowed software improvement and market entrance with a competitive product to offer to our customers."

This phase appeared to be crucial for the survival and success of the startup in getting a considerable loan that would allow it to realize the product/service to be placed on the market. Moreover, access to managerial competences was fundamental to ensure the effective and adequate management of a startup. According to the respondents, in this stage, an important role was assigned to incubators, accelerators, and coworking spaces able to offer further managerial, technical, and physical resources.

\subsection{Expansion}

In this stage, the startup is a newly born firm that has managed to consolidate and scale up the business and be self-sustainable.

The founder of Startup A during the interview claimed "The firm entered the expansion stage as new customers outside Italy were acquired and new employees were hired." The founder of Startup B stated that "The increase in employees from 2 to 15 , the opening of a workplace in Rome and the development of partnerships to launch the product in European and extra-European countries required us the improvement of coordination and strategic abilities and competences." Coordination abilities and strategic orientation were the most critical skills in this stage. Similarly, the founder of Startup E claimed that "The expansion stage was characterized by the participation into an international green industry-specific acceleration program in the US thanks to the participation to a startup contest in Italy." Also, the founder of Startup F argued that "The most important skills were strategic orientation and coordination abilities."

The founder of Startup H claimed that "My co-founder and me understood that we should modify our marketing model and sell our products via online channels in order to improve our performances. The number of employees increases together with our turnover."

An additional funding characterized the expansion stage of Startup C. As argued by the founder, "An additional funding provided by a leading Italian incubator confirmed us that we were doing a good job. Thanks to the support of this important incubator, our platform was improved and gained further visibility by becoming the main crowdfunding platform in Italy. We exploited these financial resources to hire new personnel and open a new branch in Milan." The same was for Startup D. In fact, as claimed by the founder, "The expansion stage was featured by further venture capital financing rounds, which allowed us to feed up the scale-up process. Moreover, financial resources were exploited to strengthen the skill sets with additional recruitment and the development of interesting partnerships." 
For the founder of Startup G, the development of partnerships with important companies and the obtaining of further financial resources supported him during the transition in this stage. In particular, he stated that "Thanks to important partnerships we were able to improve our customer's portfolio. We used the financial resources to improve our technologies, to open new branches in Milan and Rome and hire new staff." Similarly, the founder of Startup I stated that "We got a partnership with a worldwide partner that help us to sell our product among its customers. This allowed us to increase our turnover and invest part of it in improving the platform and hiring new staff."

The startupper should develop new skills and abilities, such as the ability to handle a higher turnover, to motivate and coordinate employees, to relate with new customers and suppliers, to look for international markets and partners, and also the ability to delegate growing tasks and activities. Also, startuppers should exhibit multifaceted and complex competencies like leadership, strategic orientation, and coordination abilities [52,53]. Finally, key activities are massive customer acquisition, back-end scalability improvements, new personnel and first executive hiring, internationalization.

\section{Discussion}

The main contribution of this work is to investigate how successful new digital firms sustain their growth-triggering resources and knowledge of the network. Organizational life cycle models assume that organizations go through predictable stages, but up to now, no generalizable models have emerged.

Preliminary results highlighted that the analyzed startups showed similarities and differences in the way the proposed model fit their evolutionary paths. For each stage, according to the interviews, some key aspects characterizing the startup life cycle were synthesized (e.g., organizational resources, startupper competences, key entrepreneurial ecosystem actors, milestones, etc.) [63]. Figure 2 reports a summary of the results.

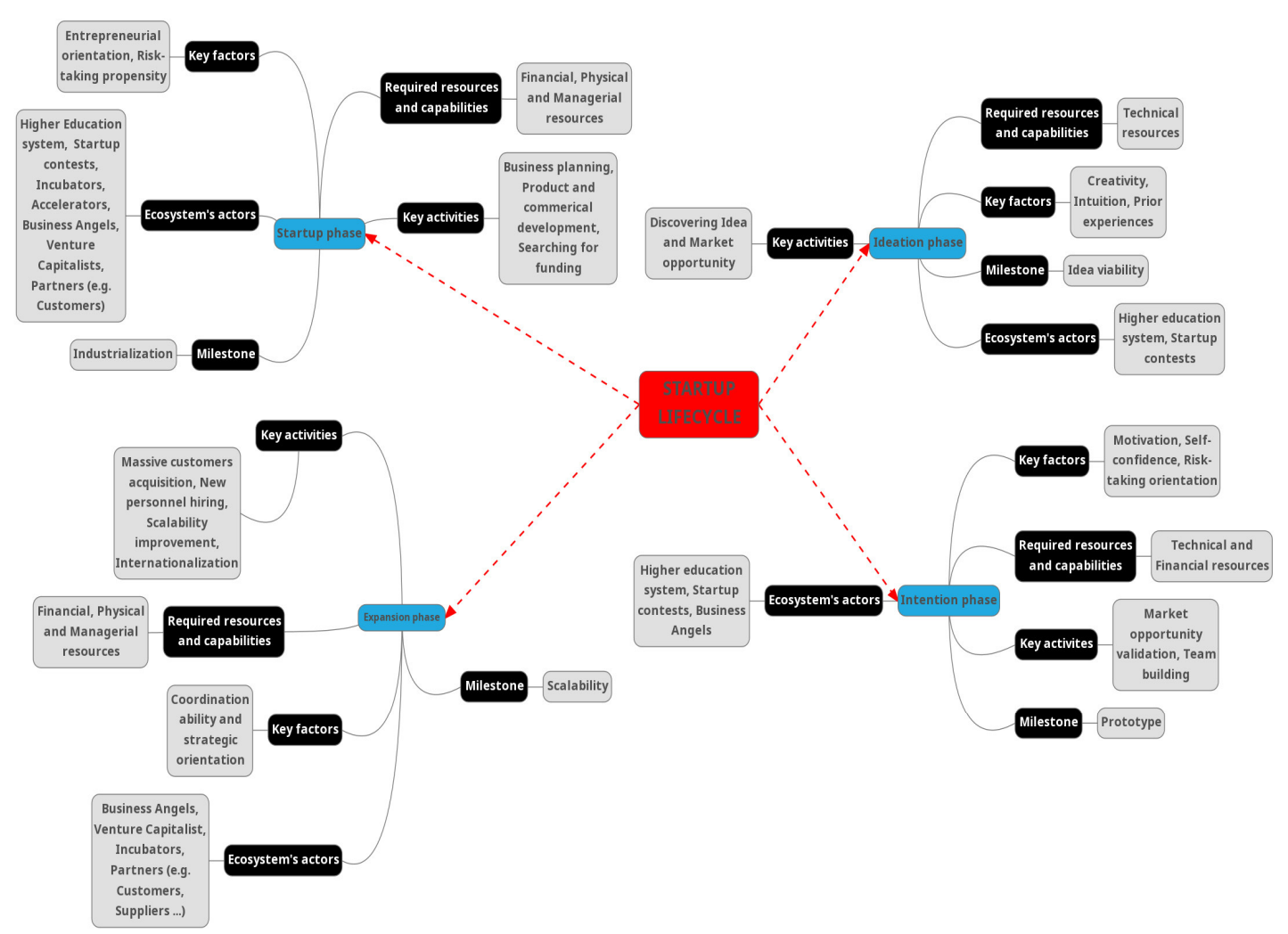

Figure 2. Summary of results (source: MindMap software: https://app.mindmup.com/). 
In general, it is possible to underline that digital technologies represented for all the interviewed startups critical resources for their birth and development. In other words, the considered startups either offered a digital product to their customers (e.g., C, D, F, H, I) or adopted digital tools to support their production processes (e.g., A, B). In the ideation stage, it emerged that intuition and creativity (at an individual level) [40,41] and technical competences and highly specific industry knowledge (at the organizational level) were key variables for the identification of the market opportunity, as well as for the development of the business idea [38]. The possibility of developing technical competences thanks to the connections with actors in the entrepreneurial ecosystem appeared to be another critical common element among the interviewed startups [16-18,20]. Several scholars have claimed that entrepreneurial culture also plays a critical role in the preliminary phase of an entrepreneurial process, although this was not confirmed by the startuppers interviewed. Furthermore, our empirical results also refuted the key role of public bodies and government in supporting founders and startuppers in the early stages.

The intention tended to emerge after aspiring startuppers were able to validate their idea by understanding its feasibility and the market potentiality of the consequent product/service [18]. To this aim, the development of collaboration networks involving different actors in the startup-friendly ecosystem was considered an inestimable source for the acquisition of key resources (e.g., financial, managerial, technical, etc.) $[16,17,20,51]$. For instance, the creation of a partnership with universities (Startups A, B), the participation in business plan competitions (Startups C, D, F) (e.g., [18]), the possibility to patent the product/service (Startup H), the access to incubators/accelerators (Startup G) [64] represented some of the central answers of the startups. From this perspective it was crucial that the process of enrichment of the team's competencies (in particular, technical ones) could go on. Of course, here, as in the next step, the possibility to obtain grants, public funds, or other financial support can play a relevant or decisive role in stimulating the emergence of the intention. Indeed, this last point can be both an injection of trust for the team (Startups C, D, and F), and a way to fill the gap in material resources (Startups A, G and I, for example, strongly needed financial resources to realize the prototype). Contrary to what has been stated in the literature, managerial resources still seem to be a non-critical resource in this specific phase. Finally, this stage can last from a few months up to two years.

The startup stage represents the formal birth of the company. Usually, the successful completion of this activity is accompanied by an external investment provided by a venture capitalist or business angels $[48,49]$. Indeed, eight out of nine startups received financing by incubators, accelerators, investors, or partners of the initiatives to industrialize the product. In some circumstances, the received amount was relevant, exceeding one million euros. While grants of public origin are usually more limited and non-repayable, private funds are more substantial and involve the entry into shared ownership of the nascent startup (equity). These subjects provide not only financial resources, such as competencies, access to the market, connections, or consultancies. It is important to note that no team started the venture without previously evaluating and planning the risks and benefits associated with their business idea. It was a decision carefully thought-out. In addition, most of the startups interviewed confirmed that technical resources were less important at this stage. This could be because this type of resource was more critical in the previous phase, in which the founders had to verify the feasibility of their idea and the scalability of the production.

The expansion represents the final stage of this model and the results of the planned efforts. At this time, even after a few months from the beginning of the startup stage, the company is issuing invoices, obtaining positive feedback from the first customers, hiring new personnel, and investing in the distribution channels The startup is now mature enough to become a small firm. The key activities of this stage are a massive customers acquisition, especially with the opening of other branches or through internationalization (cases A, B, D, F, and H), and the presence of an industrial partner who helps the small firm to access new markets, guarantees, orders, or funding (cases C, E, G and I). Of course, the entrance of new capital into the company causes a change in the properties of the startup and often 
also in the decisional system, with respect to the original team of founders. This contingency cannot be considered a novelty. As primarily stated by scientific literature, this peculiarity also underlines the importance of previous professional experiences, even if non-positive, showing the entrepreneurship as an individual's career choice [65]. However, as confirmed by this analysis, the role of experience can also be indirect, descending from family entrepreneurial influence; for instance, in cases A, B and $\mathrm{F}$, of course, the role of experience did not minimize the importance of other personal traits aspiring entrepreneurs have to possess. Within the long list of personal traits already treated by researchers, creativity, intuition, self-efficacy, and self-fulfillment seemed quite evident among the founders of cases C, D, H and I. According to the literature, results show that the most critical startupper traits are leadership, strategic orientation, and coordination [52,53].

Regarding the personal background, another statement that appeared quite evident for the majority of the founders was that the presence of individual knowledge and competencies, especially of a technical nature, was more important than the initial availability of material resources. Even so, all the interviewees involved in startup competitions and/or startup initiatives during the pre-startup phases claimed that this participation was relevant in terms of training, visibility, and creation of key relationships. Another important common aspect regards the role of business angels and/or venture capitalists. As specified, these actors play a crucial role in helping the startup by providing financial resources, networking capabilities, and managerial support. Last, but not least, universities also often guarantee a decisive provision of physical support and intangible resources within their renewed third mission [18].

To summarize, our tentative model, supported by empirical case studies, appears to be an effective tool to illustrate and synthesize the main mechanisms by which strategic choice influences the evolutionary path of a successful startup.

\section{Conclusions}

This paper aimed at understanding whether startup evolution can be conceptualized in a life cycle model intended as an unpredictable sequence of stages, where startups need to find actors with whom to collaborate to acquire knowledge and resources supporting the effectiveness and success of their mission.

The creation and implementation of collaborative networks was observed through the lens of the holistic approach to the entrepreneurial ecosystem, whose purpose is to build "bridges" between different actors through the creation of communities of best practices or entrepreneurial networks $[18,22,29]$. The creation of a specific ecosystem was suggested to ease the new digital entrepreneurship generation to where they can approach an appropriate set of knowledge, skills, financial facilitations, and entrepreneurial culture [24].

The proposed framework was developed specifically to analyze startups, as it focuses on the analysis of the activities before the new firms' launch phase. Several scholars have claimed that the kinds, the number, and the sequence of activities that nascent entrepreneurs undertake, in particular, during the pre-startup phases, have a significant influence on their ability to successfully create new ventures (e.g., [13,30-32]). Moreover, the interpretative framework tries to capture the complexity of the startup life cycle phenomenon by considering all the main aspects (e.g., required resources, key activities and factors, ecosystem actors) that can affect the survival and success of this kind of new venture.

The empirical evidence, which is based on nine case studies, seemed to confirm that firms collaborate with different actors in different stages, as knowledge and resource networks play a critical role in sustaining the evolution and success of new firms. Generally speaking, results showed the consistency and validity of the proposed interpretative framework.

The proposed model favors the analysis, planning, and management of flourishing startups' development. In this view, the proposed model contributes to reinforcing the theoretical framework that, in the last decades, scholars have built up to improve comprehension of the evolving startup 
landscape. Specifically, the proposed model supports startups in identifying the right actors of a startup ecosystem in order to get the necessary knowledge and resources and to support the realization of the key activities to achieve a successful transition in the life cycle stages. Moreover, the proposed framework can easily be adapted to analyze startups (and their life cycles) located in different countries,

Beyond this contribution to the theoretical framework related to the startup phenomenon, the life cycle model presents some practical implications for the various actors that revolve around it. For these reasons it can be seen as a comprehensive model capable of acting as an interpretative model and a managerial and political tool.

\section{Implications and Limitations}

More implications can be derived from this paper that can support the activities and the actions of different actors in the startup ecosystem.

It can represent a tool capable of supporting startuppers to make more conscious decisions regarding the resources needed to be acquired, the activities to be carried out, and the actors in the ecosystems with whom to interact and collaborate to develop effectively during their life cycles.

Moreover, aspiring startuppers may adopt the proposed life cycle model as a landmark and a guideline for the entrepreneurial path they are pursuing. It will support their decision-making process in many ways, for example, by providing a framework for what decisions should be made and what events will typically occur in different stages, or which ecosystem actors are relevant in those specific stages, thus enabling the successful transition from one life cycle stage to the next one.

The various ecosystem players (incubators, venture capitalists, accelerators, TTOs) may benefit from the model for two main reasons. First, the model, representing different stages in the progress of the business idea, allows actors to analyze the path of the potential startup and to plan their activities and actions, thus, improving their effectiveness. Also, for each actor, the proposed model can be a useful tool to support its own startup portfolio management.

From the policy implications viewpoint two main implications can be drawn:

(a) the creation of an entrepreneurial ecosystem representing an appropriate environment to foster collaborative networks between actors able to support the generation of new digital entrepreneurship and startups must be considered as a priority component of any national and local policy addressed to innovation and technological development. This priority is further evident when one considers the cross-fertilization effects this policy can have on the innovation and competitive capabilities of the industrial system as a whole;

(b) the interpretative framework can be considered a tool able to assist policy makers in defining differentiated measures and incentives to foster the development and growth of successful startups through the transition from one phase to another, as well for the definition of policy for stimulating the startup birth rate. The model can be a macro analysis tool within the startup phenomenon and, in particular, on the stage breakdown structure of the startup landscape as a whole.

For practitioners it can be an analysis tool to identify and propose a more appropriate and specialized stage-specific consultancy to be more effective in reaching development paths. In addition, practitioners can benefit from the support of managing their startup portfolio.

As for the research point of view, this model intends to contribute to understanding the behaviors of startups (and startuppers), which, by their very nature, are manifold and varied. In particular, researchers should contribute to reinforcing the research path that in the last decades scholars are building up to improve the comprehension of the evolving startup landscape. In this view further research is needed.

This study presents some limitations. The first limit is rooted in the adopted empirical approach and in its explorative nature. The use of a narrow number of case studies limits the generalizability and scalability of results. Furthermore, as a small number of cases brought a slight modification of the 
model, the more case studies, the more reliable will be the model. A second limitation deals with the localization of the case study proposed. Different environmental contexts can provide different levers on the startuppers' intentions and the actors in the startup ecosystem, thus influencing the evolution of the startup life cycle. For a greater generalizability of the results, industry-related aspects may also have an influence and require a greater industry representation of case studies to be analyzed.

Both these limitations can be overcome by extending the empirical analysis to a broader number of case studies rooted in new and different country contexts. Then, the proposed interpretative framework should be further validated by involving an appropriate sample of startups. Both these steps are part of our research program.

A third limitation concerns the failure to take into account the negative unexpected events that startups typically face during their life cycle, which can seriously compromise their survival capacity (e.g., market risks, financial risks, legal risks, technological and operational risks, systemic risks, competition, etc.). In particular, this lack depended mainly on the fact that we decided to focus on successful startups, even though, when present, we also highlighted how some startups faced these challenges, thanks to the support of the various players in the ecosystem.

Author Contributions: Conceptualization: R.P., I.Q., P.R. and A.T.; Methodology: R.P., I.Q. and P.R.; Formal analysis: I.Q. and P.R.; Investigation: R.P., I.Q., P.R. and A.T.; Data curation: I.Q. and P.R.; Writing-Original draft preparation: R.P., I.Q., P.R. and A.T.; Writing-Review and editing: R.P., I.Q. and P.R.; Supervision: I.Q. and P.R. All authors have read and agreed to the published version of the manuscript.

Funding: This research received no external funding.

Conflicts of Interest: The authors declare no conflict of interest.

\section{References}

1. Audretsch, D.B. Entrepreneurship capital and economic growth. Oxf. Rev. Econ. Policy 2007, 23, 63-78. [CrossRef]

2. Clarysse, B.; Bruneel, J. Nurturing and growing innovative startups: The role of policy as integrator. RED Manag. 2007, 37, 139-149. [CrossRef]

3. Chatterji, A.; Delecourt, S.; Hasan, S.; Koning, R. When does advice impact startup performance? Strateg. Manag. J. 2019, 40, 331-356. [CrossRef]

4. Giraudo, E.; Giudici, G.; Grilli, L. Entrepreneurship policy and the financing of young innovative companies: Evidence from the Italian Startup Act. Res. Policy 2019, 48, 103801. [CrossRef]

5. Rippa, P.; Secundo, G. Digital academic entrepreneurship: The potential of digital technologies on academic entrepreneurship". Technol. Forecast. Soc. Chang. 2019, 146, 900-911. [CrossRef]

6. Blank, S.; Dorf, B. The Startup Owner's Manual: The Step-By-Step Guide for Building a Great Company; K\&S Ranch: Hoboken, NJ, USA, 2012.

7. Melegati, J.; Chanin, R.; Wang, X.; Sales, A.; Prikladnicki, R. Enablers and Inhibitors of Experimentation in Early-Stage Software Startups. In PROFES 2019: Product-Focused Software Process Improvement; Franch, X., Männistö, T., Martínez-Fernández, S., Eds.; Lecture Notes in Computer Science 11915; Springer: Cham, Switzerland, 2019.

8. Mukti, I.Y.; Wibowo, A.P.W.; Galih, S. Lessons Learned to Increase the Digital Startups Success Rate. Glob. Bus. Manag. Res. 2019, 11, 226-234.

9. Wen-Hsiang, L.; Lin, C.C. Constructing business incubation service capabilities for tenants at post-entrepreneurial phase. J. Bus. Res. 2015, 68, 2285-2289. [CrossRef]

10. Nunez, L.G. The process and problems of business Startups. In Pensamiento y Gestión: Revista de la División de Ciencias Administrativas de la Universidad del Norte; Univeristat del Norte: Barranquilla, Colombia, 2007; Volume 22, pp. 232-255. Available online: https://www.redalyc.org/pdf/646/64602207.pdf. (accessed on 12 November 2020).

11. Van Gelderen, M.; Thurik, R.; Bosma, N. Success and risk factors in the pre-startup phase. Small Bus. Econ. 2006, 26, 319-335. [CrossRef] 
12. Barazandeh, M.; Parvizian, K.; Alizadeh, M.; Khosravi, S. Investigating the effect of entrepreneurial competencies on business performance among early stage entrepreneurs Global Entrepreneurship Monitor" (GEM 2010 survey data). J. Glob. Entrep. Res. 2015, 5, 18. [CrossRef]

13. Honig, B.; Samuelsson, M. Planning and the entrepreneur: A longitudinal examination of nascent entrepreneurs in Sweden. J. Small Bus. Manag. 2012, 50, 365-388. [CrossRef]

14. Van Gelderen, M.; Thurik, R.; Patel, P. Encountered problems and outcome status in nascent entrepreneurship. J. Small Bus. Manag. 2011, 49,71-91. [CrossRef]

15. Salamzadeh, A.; Kawamorita, K.H. Startup Companies: Life Cycle and Challenges. In Proceedings of the 4th International EEE Conference, Belgrade, Serbia, 3-6 June 2015.

16. Berger, E.S.; Kuckertz, A. Female entrepreneurship in startup ecosystems worldwide. J. Bus. Res. 2016, 69, 5163-5168. [CrossRef]

17. Kollmann, T.; Stöckmann, C.; Hensellek, S.; Kensbock, J. European Startup Monitor. 2016. Available online: https://europeanstartupmonitor.com/fileadmin/esm_2016/report/ESM_2016.pdf (accessed on 12 November 2020).

18. Passaro, R.; Quinto, I.; Thomas, A. Start-up competitions as learning environment to foster the ntrepreneurial process. Int. J. Entrep. Behav. Res. 2017, 23, 426-445. [CrossRef]

19. Schwartz, M.; Goethner, M.; Michelsen, C.; Waldmann, N. Start-up competitions as an instrument of entrepreneurship policy: The German experience. Eur. Plan. Stud. 2013, 21, 1578-1597. [CrossRef]

20. Tripathi, N.; Seppänen, P.; Boominathan, G.; Oivo, M.; Liukkunen, K. Insights into startup ecosystems through exploration of multi-vocal literature. Inf. Softw. Technol. 2019, 105, 56-77. [CrossRef]

21. Shwetzer, C.; Maritz, A.; Nguyen, Q. Entrepreneurial ecosystems: A holistic and dynamic approach. J. Ind. Univ. Collab. 2019, 1, 79-95. [CrossRef]

22. Mason, C.; Brown, R. Entrepreneurial Ecosystems and Growth Oriented Entrepreneurship; OECD: The Hague, The Netherlands, 2014; Available online: https://www.oecd.org/cfe/leed/entrepreneurial-ecosystems.pdf (accessed on 12 November 2020).

23. Isenberg, D.; Onyemah, V. Fostering scale up ecosystems for regional economic growth. Innov. Technol. Gov. Glob. 2016, 11, 60-79.

24. EC (European Commission). Digital Entrepreneurship Scoreboard 2015. Bruss. Dir. Gen. Intern. Mark. Ind. Entrep. 2016. Available online: https://ec.europa.eu/growth/content/digital-entrepreneurship-scoreboard-2015-0_en (accessed on 12 November 2020).

25. EC (European Commission). Fuelling Digital Entrepreneurship in Europe. Backgr. Pap. 2014. Available online: http://ec.europa.eu/DocsRoom/documents/5313/attachments/1/translations (accessed on 12 November 2020).

26. Nambisan, S. Digital entrepreneurship: Toward a digital technology perspective of entrepreneurship. Entrep. Theory Pract. 2017, 41, 1029-1055. [CrossRef]

27. Nambisan, S.; Baron, R.A. Entrepreneurship in innovation ecosystems: Entrepreneurs' selfregulatory processes and their implications for new venture success. Entrep. Theory Pract. 2013, 37, 1071-1097. [CrossRef]

28. Thomas, A.; Passaro, R.; Quinto, I. Developing entrepreneurship in digital economy: The ecosystem strategy for startups growth. In Strategy and Behaviors in the Digital Economy; Orlando, B., Ed.; IntechOpen: London, UK, 2020. [CrossRef]

29. Isenberg, D. The Entrepreneurship Ecosystem Strategy as a New Paradigm for Economic Policy: Principles for Cultivating Entrepreneurship. Babson Park Babson Coll. 2011. Available online: http://www.innovationamerica.us/images/stories/2011/The-entrepreneurship-ecosystem-strategyfor-economic-growth-policy-20110620183915.pdf (accessed on 12 November 2020).

30. Carter, N.M.; Gartner, W.B.; Reynolds, P.D. Exploring startup event sequences. J. Bus. Ventur. 1996, 11, 151-166. [CrossRef]

31. LeBrasseur, R.; Zanibbi, L.; Zinger, T.J. Growth momentum in the early stages of small business startups. Int. Small Bus. J. 2003, 21, 315-330. [CrossRef]

32. Liao, J.; Welsch, H.; Tan, W.-L. Venture gestation paths of nascent entrepreneurs: Exploring the temporal patterns. J. High Technol. Manag. Res. 2005, 16, 1-22. [CrossRef]

33. Phelps, R.; Adams, R.; Bessant, J. Life cycles of growing organizations: A review with implications for knowledge and learning. Int. J. Manag. Rev. 2007, 9, 1-30. [CrossRef]

34. Noennig, J.R.; Scheler, A.M.; Piskorek, K.; Barski, J. Towards Knowledge Ecosystems: Modelling Knowledge Dynamics in Environmental Systems. Procedia Comput. Sci. 2014, 35, 1360-1369. [CrossRef] 
35. Nambisan, S.; Lyytinen, K.; Majchrzak, A.; Song, M. Digital Innovation Management: Reinventing innovation management research in a digital world. Mis Q. 2017, 41, 223-238. [CrossRef]

36. Lichtenstein, B.; Bergmann, M.; Brush, C.G. How do "resource bundles" develop and change in new ventures? A dynamic model and longitudinal exploration. Entrep. Theory Pract. 2001, 25, 37. [CrossRef]

37. West, G.P., III; Taplin, I.M. Making wine and making successful wineries: Resource development in new ventures. Int. J. Organ. Anal. 2016, 24, 123-144. [CrossRef]

38. Marmer, M.; Herrmann, B.L.; Dogrultan, E.; Berman, R.; Eesley, C.; Blank, S. Startup genome report extra: Premature scaling. Startup Genome 2011, 10, 1-56.

39. Duckworth, V.; Farrell, F.; Rigby, P.; Smith, R.M.; Sardeshmukh, S.R.; Combs, G.M. Understanding gender, creativity, and entrepreneurial intentions. Educ. Train. 2016, 58, 263-282. [CrossRef]

40. Tu, C.; Yang, S. The role of entrepreneurial creativity in entrepreneurial processes. Int. J. Innov. Manag. Technol. 2013, 4, 286. [CrossRef]

41. Passaro, R.; Quinto, I.; Thomas, A. Supporting entrepreneurship policy: An overview of Italian start-up competitions. Int. J. Entrep. Innov. Manag. 2020, 24, 1-30. [CrossRef]

42. Livi, C.; Jeannerat, H. Born to be Sold: Startups as Products and New Territorial Life Cycles of Industrialization. Eur. Plan. Stud. 2015, 23, 1953-1974. [CrossRef]

43. Witt, P. Entrepreneurs' networks and the success of startups. Entrep. Reg. Dev. 2004, 16, 391-412. [CrossRef]

44. Davidsson, P.; Honig, B. The role of social and human capital among nascent entrepreneurs. J. Bus. Ventur. 2003, 18, 301-331. [CrossRef]

45. Reynolds, P.D.; White, S.B. The Entrepreneurial Process: Economic Growth, Men, Women, and Minorities; Quorum Books: Westport, CT, USA, 1998.

46. Keating, A.; McLoughlin, D. The entrepreneurial imagination and the impact of context on the development of a new venture. Ind. Mark. Manag. 2010, 39, 996-1009. [CrossRef]

47. Kim, P.H.; Aldrich, H.E.; Keister, L.A. Access (not) denied: The impact of financial, human, and cultural capital on entrepreneurial entry in the United States. Small Bus. Econ. 2006, 27, 5-22. [CrossRef]

48. Chang, S.J. Venture capital financing, strategic alliances, and the initial public offerings of Internet startups. J. Bus. Ventur. 2004, 19, 721-741. [CrossRef]

49. Davila, A.; Foster, G.; Gupta, M. Venture capital financing and the growth of startup firms. J. Bus. Ventur. 2003, 18, 689-708. [CrossRef]

50. Giudici, G.; Rossi-Lamastra, C. Chapter 12: Crowdfunding of SMEs and Startups: When Open Investing Follows Open Innovation, Res. Open Innov. SMEs; World Scientific: Singapore, 2018; pp. 377-396. [CrossRef]

51. Paschen, J. Choose wisely: Crowdfunding through the stages of the startup life cycle. Bus. Horiz. 2017, 60, 179-188. [CrossRef]

52. Brannback, M.; Carsrud, A. Do they see what we see? A critical Nordic tale about perceptions of entrepreneurial opportunities, goals and growth. J. Enterprising Cult. 2008, 16, 55-87. [CrossRef]

53. Ensley, M.D.; Carland, J.W.; Carland, J.C. Investigating the existence of the lead entrepreneur. J. Small Bus. Manag. 2000, 38, 59.

54. Eisenhardt, K.M.; Graebner, M.E. Theory building from cases: Opportunities and challenges. Acad. Manag. J. 2007, 50, 25-32. [CrossRef]

55. Eisenhardt, K.M. Building theories from case study research. Acad. Manag. Rev. 1989, 14, 532-550. [CrossRef]

56. Yin, R.K. Case Study Methodology; Sage Publication: London, UK, 2003.

57. Gibbert, M.; Ruigrok, W.; Wicki, B. What passes as a rigorous case study? Strateg. Manag. J. 2008, 29, $1465-1474$. [CrossRef]

58. Eden, C.; Ackermann, F. Strategy Making: The Journey of Strategic Management; Sage Publication: London, UK, 1998.

59. Noblit, G.W.; Hare, R.D. Meta-Ethnography: Synthesizing Qualitative Studies; Sage: Newbury Park, CA, USA, 1988.

60. MISE (Ministero dello Sviluppo Economico). Relazione al Parlamento Sullo Stato di Attuazione Della Normativa a Sostegno Delle Startup e Delle PMI Innovative, Rome, September. 2015. Available online: https://www.mise.gov.it/images/stories/documenti/startup_relazione_annuale_al_2017.pdf (accessed on 12 November 2020).

61. Patton, M.Q. Qualitative Evaluation and Research Methods, 2nd ed.; Sage: Newbury Park, CA, USA, 2002.

62. Urbinati, A.; Chiaroni, D.; Chiesa, V.; Frattini, F. The role of digital technologies in open innovation processes: An exploratory multiple case study analysis. RED Manag. 2020, 50, 136-160. [CrossRef] 
63. Ye, Q. New-born startups performance: Influences of resources and entrepreneurial team experiences. Electron. Bus. 2018, 17, 1-15. [CrossRef]

64. Miles, M.P.; de Vries, H.; Harrison, G.; Bliemel, M.; De Klerk, S.; Kasouf, C.J. Accelerators as authentic training experiences for nascent entrepreneurs. Educ. Train. 2017, 59, 811-824. [CrossRef]

65. Passaro, R.; Quinto, I.; Thomas, A. The impact of higher education on entrepreneurial intention and human capital. J. Intellect. Cap. 2018, 19, 135-156. [CrossRef]

Publisher's Note: MDPI stays neutral with regard to jurisdictional claims in published maps and institutional affiliations.

(C) 2020 by the authors. Licensee MDPI, Basel, Switzerland. This article is an open access article distributed under the terms and conditions of the Creative Commons Attribution (CC BY) license (http://creativecommons.org/licenses/by/4.0/). 